\title{
The Effect of Value Co-creation on Innovation Performance: The Mediating Role of Customer Perceived Value
}

\author{
Samuel Kofi Otchere* Tian Hong-Yun \\ Winfred Okoe Addy Richard Gyamfi Kumaning \\ Jiangsu University, School of Management Science
}

\begin{abstract}
The study assessed the effect of value co-creation on innovation performance with a mediating effect of customer perceived value in the telecommunication industry in Ghana. The study used 240 respondents and an online survey for a period of two months thus June 2019 and July 2019. The study concludes that value cocreation has positive and significant impact on innovation performance and customer perceived value has insignificant impact on innovation performance but value co-creation has positive impact on customer perceived value. However, the study recommends further studies into the area of value co-creation and innovation performance with products and services specific dimensions to measure innovation success.
\end{abstract}

Keywords: Value co-creation (VC); Customer perceived value (PV); Innovation performance (PFR); Telecommunication industry; Ghana

DOI: $10.7176 / \mathrm{EJBM} / 11-27-05$

Publication date:September $30^{\text {th }} 2019$

\section{Introduction}

The position of buyers in the industrialized sector in economies has intensely transformed; moreover, the influence of the connected, informed and active buyers keep rising through information access, a global view, networking and experimentation (Prahalad \& Ramaswamy, 2004). Value co-creation as concept can be traced from the 1980s and exist as much-discussed topic in academic pursuits to date (Martelo et al., 2013). In order to stay viable and driven (Pine \& Gilmore, 1999; Chesbrough, 2003; Prahalad \& Ramaswamy, 2004; Vargo \& Lusch, 2004; Von Hippel, 2005) are championing that the perception of firms with regards to their exterior stakeholders should be fundamentally altered due to the current trend of theories in innovation management, knowledge management, and marketing management. Consequently, modern thinking in many spheres suggests that the roles of customer and seller are becoming increasingly obscured hence users participate in content creation and product development, support each other in product use and promote products, services and/or brands to other customers (Hoyer et al. 2010; Kristensson et al., 2008; Nambisan and Baron, 2009; Dholakia et al., 2009; De Bruyn and Lilien, 2008; Libai et al., 2010).

More emphasis has been laid on the concept of experience economy which is assumed to have had large impact and takes a broad and historical perspective on the issue. Moreover, it has been widely accepted that the experience of an economy is the next stage in the progression of economic value, following the service economy (Pine \& Gilmore, 1999). This theory affirms that each step in the progression of economic value is driven by commoditization of the firm's offering and the need to find new ways to add value. However, firms need to customize their offerings in order to avoid commoditization and customizing services will result in experiences; as experiences are gained as a result of the interaction between the consumer and the organized event of the firm. There is a notion that the only party that can directly benefit from innovation is the consumers by involvement in the high participation of consumers in innovation (Von Hippel, 2005). Consumers' involvement in the innovation process of firms has enormous advantages because the needs of consumers are highly diverse and the chance that a product or service on the market is mostly what the consumer need is perhaps low. Therefore, it will be imperative and valuable for firms to involve consumers in the innovation advancement process. Moreover, consumers are willing to share their novelties which they have been done by themselves because it is the only obvious way to further develop and improve it.

Prior studies have not limited to scientific research only but the consulting world has also been highly involved in the developing of thoughts and contributions on this phenomenon (Capgemini, 2007; Global Commerce Initiative, 2008; Lawer, 2006; Pater, 2009; Martelo Landroguez et al., 2013; Leroi-Werelds et al., 2014). It has become imperative for this study to add up to existing pieces of literature hence the objective is to test whether consumer participation enhances firms' innovation performance with customers' perceived value as a pivot. In this study, the main contribution is to assess the impact of value co-creation with a mediating effect of customer perceived value as firm's step of attempting to create joint value with its customers while firm's innovation performance is the outcome of this process measured by the perception of the customer of the value created. The concept of the study comprises of conceptual framework, theoretical literature review, methodology, results and findings discussion as well as the conclusion and limitation to the study and future direction. 


\subsection{Conceptual framework}

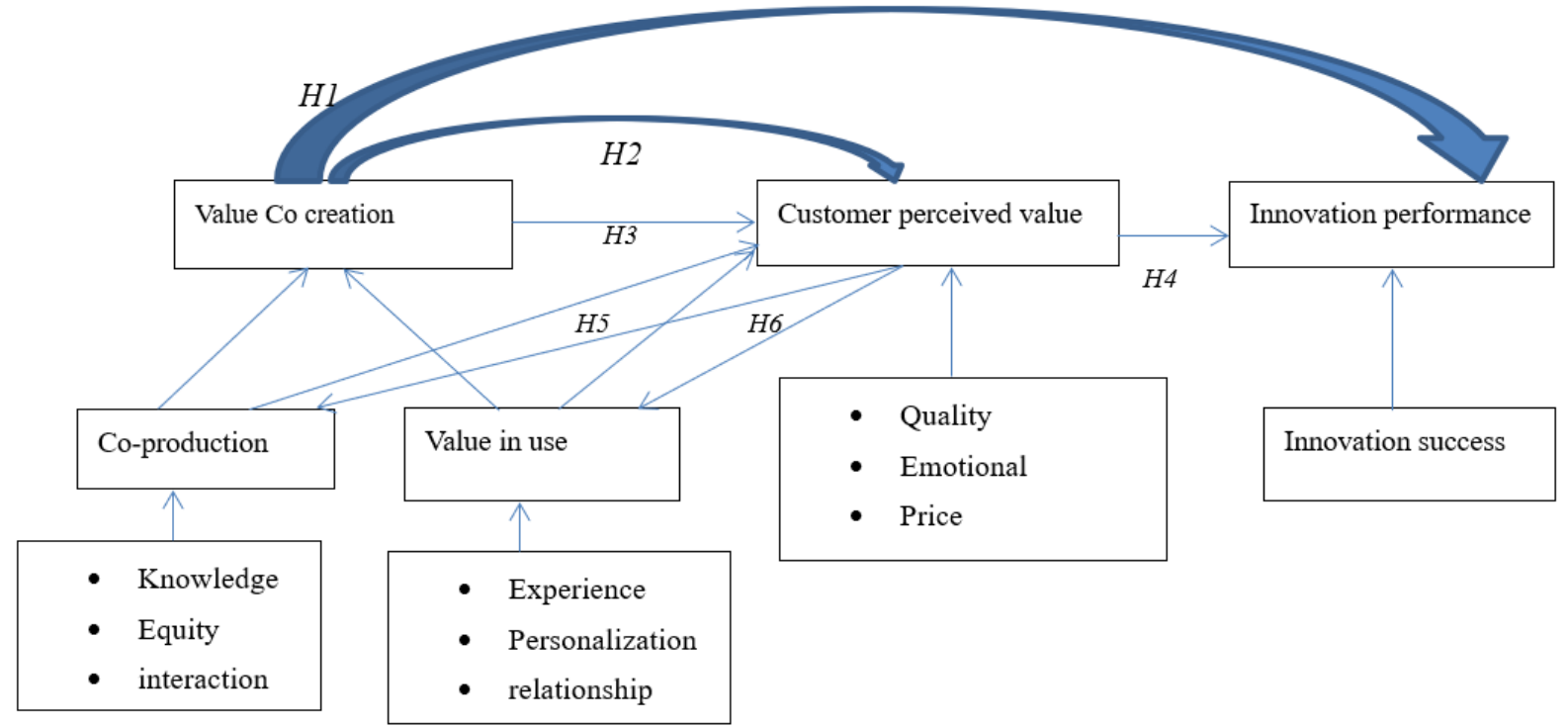

Figure 1: Conceptual framework

\section{Theoretical literature review}

\subsection{Value co-creation}

Ideally, the notion of value being created with customers centered rather than firm delivering value to its customers enjoins the ten foundational premises of what is now known as the service-dominated logic of marketing (Vargo \& Lusch, 2008). The idea that championed into the curation of this ten foundational premises can be traced down to the influential papers by (Vargo \& Lusch, 2004; Prahalad \& Ramaswamy, 2004) created much academic attention into the concept of value co-creation by a business with its customers (Galvagno \& Dali, 2014; Fellesson \& Salomonson, 2016; Ranjan \& Read, 2016). Value co-creation can be described in three spheres; the firms' sphere, customers' sphere and joint sphere (Gronroos \& Voima, 2013). In the business' sphere, the businesses provide and create value thus potential value but not actual value; in the customer sphere the customer independently creates value through the production and provision of goods and services by business and joint sphere can be described as the emerging opportunity for co-creation through dealings between the business and the customer (Gronroos \& Voima, 2013).

\subsubsection{Dimensions of value co-creation}

Prior studies by Prahalad \& Ramaswamy (2004) to unravel the underlying dimensions surrounding value cocreation created a model which they named DART model of value co-creation which figuratively means dialogue, access, risk assessment, and transparency. Where dialogue means two-way interaction and engagement between the firm and its customers. Most importantly, the dialogue does not only involve the firms listening to customers but also customers become an equal contributor to the interaction. Access refers to allowing customers to use information and tools available to the firm. Risk assessment curtails the understanding of the customer risks involved and assuming the customer will play a major role in the value creation process; which normally considers whether consumers should take the responsibility for some of the risks if they are to co-create value. Transparency is the process where the traditional asymmetry in knowledge and information between the firm and customers are dealt with. There are two diverging views of value co-creation thus customer-centric perspective and firm centric perspective (Galvagno \& Dalli, 2014). In the perspective of customer-centric view, Ranjan \& Read (2016) posit that there are two dimensions of value co-creation namely; value-in-use and coproduction. Value in use can be referred to as customers' use and experience of products or services and coproduction is the insights through market research to active participation in the development of product and creation of content by the customer's involvement (Vargo \& Lusch, 2004). Further studies by Ranjan \& Read (2016) recommended that there should be sub-dimensions to the two-dimension proposed by Vargo and Lusch (2004) to augment the understanding of customer-centric co-creation hence the proposal of the following;

- Experience (Value in use): this can be explained as the emotional value and memorability of the interaction between the customer and the firm. It is a fundamental linkage that a firm creates through its products through the interaction by the customer and the firm's product or service.

- Personalization (Value in use): the degree of uniqueness that firms provide in their products and services at the individual customer level can be known as personalization.

- Relationship (Value in use): relationship accounts for the measure to which there is an engagement with 
and attachment to the service interaction to the firm involved.

- Knowledge sharing (co-production): this is the extent to which firms provide the platform for customers to share their suggestions and ideas based on their past or previous experience to help to improve their products or services to create future value for the customers.

- Equity (co-production): this refers to the readiness of businesses to distribute control of its business processes and allow the customer to be involved in the process. This could result in the customers being transparent in their needs to enable the firms to respond to their needs and ensures the customer to be an equal partner in the interaction.

- Interaction (co-production): As far as knowledge and equity dimensions can take place outside of the service interaction, creating value through interaction is dependent on dynamic involvement of the firm and the customer in the service interaction process as well as dialogue between the customer and the firm. The opportunity lies on the customer to express his/her needs while the service interaction is taking place and playing a proactive role in the process keenly.

There is sparse research in the area of value co-creation (Vega-Vazquez et al. 2013; Ind \& Coastes, 2013). A study on 327 firms in a research conducted by Tijmes (2010) to find out the role that value co-creation plays in firm's performance, the study found that there is no actual impact of value co-creation on innovation success but the moderation effect of the number and type of business functions involved make this relationship significant.

\subsection{Customer perceived value}

Customer perceived value can be defined as "the difference between the prospective customer's evaluation of all the benefits and the costs of a product or services and the perceived alternatives" (Kotler \& Keller, 2012). Surprisingly, the topic of customer perceived value gained attention in the 1990s and has become the central focus of many business successes. Perhaps, it has not been accorded with much attention despite its perceived importance in business circles (Martelo Landroguez et al., 2013).

\subsubsection{Dimensions of Customer perceived value}

A study on customer perceived value concluded that there are two schools of thought that surround the topic thus value as uni-dimensional construct and multi-dimensional construct (Sanchez-Fernandez et al., 2007). However, the construct termed as uni-dimensional assumes that perceived value can be measured by single or self-reported items. Even though perceived value could be the result of a set of multiple antecedents, it is still considered as a singular concept and it takes mostly a utilitarian point of view of perceived value. However, quality, price, and reputation are antecedents of value hence the construct is reflective rather than formative. Customer perceived value has many other virtues which are mostly defined by customers, not the firm; it is personal and unique to every customer (Leroi-Werelds et al., 2014). Moreover, it can be seen as importantly circumstantial, timedependent and location-dependent; it is also based on interaction. Perhaps, it is experiential thus the value lies in consumption not purchasing. There have been five views of the multi-dimensional school of thought: the customer value hierarchy, utilitarian and hedonic value, axiology or value theory, consumption-value theory and Holbrook's typology of perceived value (Sanchez-Femandez \& Iniesta-Bonillo, 2007).

Arguably, the use of uni-dimensional and multi-dimensional construct have convincing and merit grounds but it is clear that multi-dimensional have higher grounds with regards to the evidence of five research streams supporting its advanced and academically validated measurement scale in Sweeny \& Soutar's (2001) PERVAL scale which was proposed by Walsh et al.(2014).

\subsection{Value co-creation and innovation performance (success)}

Customers are widely considered as life and most importantly the resource of firms (Salomo et al. 2003). The customers who possess the context of useful information which is valuable to firms are considered as current or potential customers because the context of the user information is the factor of their products or services that should be complied with (Von Hippel, 2005). The most treasured resource to firms is customer knowledge because a firm that features customer knowledge into its business process is far better off and has competitive advantage over its competitors. In the context of innovation process, cooperation with customers is an extension of the inter-organizational relationships strategy which reduces market-related risks by decreasing the information irregularity between the firm and its customers. An innovation that is termed as successful is the process whereby a firm is able to provide products and services that fit with customers' needs by embedding customer knowledge through co-creation. Innovation success measurement comes into two forms; operational and market antecedents to innovation success. The operational antecedents are product quality, unit cost and time-to-market and market antecedents are customer satisfaction and relative sales (Tatikonda et al. 2001; Carbonell et al. 2009).

\subsection{Overview of the telecommunication industry in Ghana}

In Ghana the telecommunication industry comprises radio, television, fixed and mobile telephones, and the 
internet. A World Bank (2013) report positioned the industry as the main economic sector of the economy of Ghana due to the Ghana liberal policy around Information and communication technology (ICT). The various investments in the sector can be recorded as $65 \%$ is for ICT, $8 \%$ is for communications and $27 \%$ is divided for public administration (Ghana Internet Usage and Telecommunications, 2013). As of 2010, two fixed-line and six mobile phone companies had the authorization to operate. Currently, the mobile phone companies are Mobile Telecommunications Network (MTN), Vodafone, AirtelTigo, and Glo. The competition among mobile phone companies has brought about astronomical growth in mobile usage penetration or patronage. However, there are 34.57 million subscribers representing $119 \%$ penetration rate.

The study's motivation stems from these figures as can be seen as an innovation industry with a lot of customers hence the reason to choose the mobile phone companies as the case study.

\section{Ghana: Mobile Phone Use}

$\%$ of Respondents Who Last Used a Mobile Phone in That Period

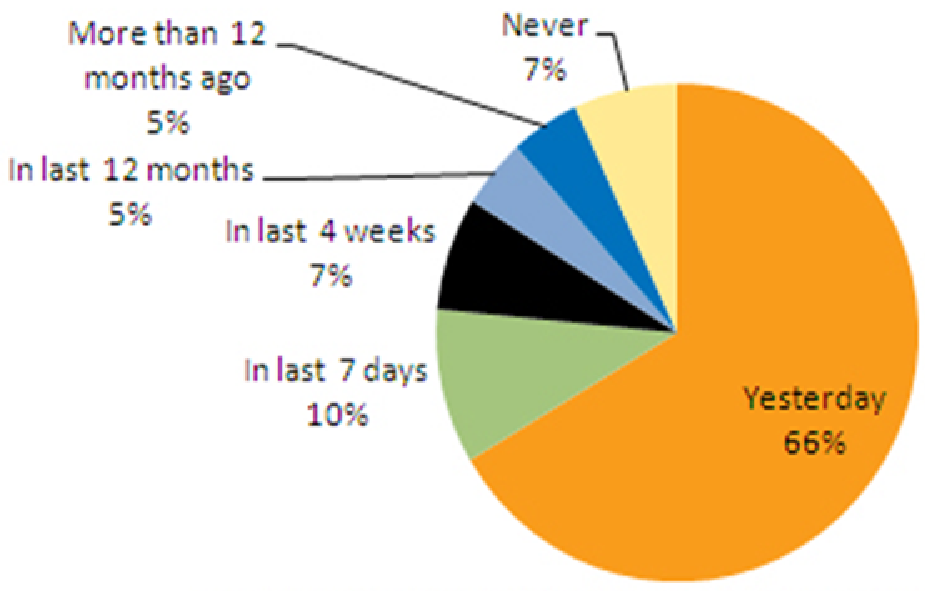

AudienceScapes National Survey of Ghana, July 2009. N=2051 adults (15+)

Figure 2: Mobile phone usage survey

\subsection{Hypotheses development}

The study developed five hypotheses based on the overall impact of value co-creation, due to the fact that there is no abundance of business resources and examining how balancing co-creation mix can help firms to prioritize their resource allocation and lastly, the notion that co-creation should be part of firms' innovation agenda. The study utilized three theoretical constructs that form the basis of the research hypotheses. The first one is the measurement of customer perceived value thus PERVAL(Sweeney \& Soutar, 2001; Walsh et al., 2014; Pierre, 2016) with the dimensions of Price, Quality, Emotional and Social value as measurement of customers' perceived value. The second construct is value co-creation construct which comprises of value in use and coproduction measuring the firm's efforts at co-creation in the joint sphere (Gronroos \& Voima, 2013). Lastly, innovation performance is measured by innovation performance which measured by the success of innovation thus by market antecedents i.e customer satisfaction (Tatikonda et al. 2001; Carbonell et al. 2009; Tijmes, 2010).

\subsubsection{Value co-creation, customer perceived value and innovation success}

With regard to innovation, it has been established that the most important aspect of product's uniqueness is the level of its innovation. Innovation has enormous ways and can vary according to its types such as new to the market and new to the firm and in its elements such as new technology and new product qualities. When an innovation scores positive remarks on quality, costs, time to market, customer satisfaction and relative sales, in this case then the innovation can be referred to as a success.

H1: There is a positive impact of value co-creation on innovation performance

H2: There is a positive impact of customer perceived value on innovation success

H3: There is a positive impact of value co-creation and customer perceived value on innovation success

\subsubsection{Value co-creation and customer perceived value}

At its peak, value co-creation enables customers to partake actively in the value generated through direct or indirect interactions with a firm and its business processes. Firms can only co-create value with their customers at points of interaction and enhance this process by understanding their customers' behavior and effectively managing the seeming interaction processes (Gronross \& Voima, 2013). It requires active or proactive efforts and huge investments from firms and also important to understand what value these efforts add up for the firm. It 
is reasonable to expect that successful co-creation will lead to an increase in customer perceived value due to the importance attached to customer value perception.

H4: There is a positive and significant impact of value co-creation on customer perceived value

\subsubsection{Co-production and value-in-use have differential impacts on customer perceived value}

The two dimensions of value co-creation thus co-production and value in use proposed by Ranjan and Read (2016) make an interesting exposure to question how firms allocate their resources. Co-production focuses on the interaction between the firms and customers and obligate firms to put greater efforts on their direct interactions with customers and how to co-create value with them in these interactions. Consequently, value in use curtails the customer's independent value creation process through their experience of the firm's products and services. Therefore, it is important to examine which dimension of value co-creation has greater impact on customer value perception.

H5: Do co-production and value in use have differential impacts on customer perceived value

2.5.4 How do the four dimensions of customer perceived value differential impacted by co-production and value in use

Customer value perception has underlying dimensions of quality, emotional value, price and social value which the study has adopted from the PERVAL model as explained in Walsh et al. (2014). On this note, the study would like to examine the individual effect on each dimension on co-production and value in use to ascertain the direction at which the telecommunication industry should invest in.

H6: there is a positive impact of quality, emotional value, price and social value on co-production and value in use

\section{Methodology}

\subsection{Research design and data collection}

Research design as described by Saunders \& Lewis (2012) consisting of research philosophy, approach, strategy, time horizon, and technique. The study followed a deductive approach such that the theoretical propositions of value co-creation, customer perceived value, and innovation performance as well as their relationships are analyzed through research strategy designed specifically for the purpose. The data was collected through the use of an online survey. The questionnaire was categorized into four folds; first fold contained the demographic questions, second fold measured the respondents' perceived value of the telecommunication companies in Ghana as they rated using the reduced PERVAL measurement scale (Walsh et al., 2014). The third fold of the questionnaire contained the questions with regards to the perception of respondents based on value co-creation (Ranjan \& Read, 2016). The final fold measured the innovation performance of the telecommunication industry (Tijmes, 2010). The data were collected within a period of two months spanning from June 2019 through to July 2019 .

\subsection{Sample selection}

The sample of the study was drawn from the customer population of the telecommunication industry in Ghana hence the sample size was 240. Since this study used an online survey to reach out its respondents, the convenient random sampling technique was employed in order to reach out to respondents.

\subsection{Scale of measurement and analytical technique}

The study used one independent variable (value co-creation), one mediating variable (customer perceived value) and one dependent variable (innovation performance). The independent variable had two dimensions and the two dimensions also had three sub-dimensions each. However, the mediating variable had four dimensions and the dependent variable had only a dimension. The study employed the 7 Likert scale measurement due its preference as it allows for more statistical variability (Salkind, 2010). The analytical technique used by the study to analyze the data was Software Package for Social Scientists (SPSS) and Amos structural equation modeling (SEM) for its statistical inference.

\subsection{Descriptive statistics of respondents}

The study collected the demographic data of the respondents and table 1 reports the information. From table 1 , it can be established that the respondents by gender were 165 of Males and 75 of females representing $68.75 \%$ and $31.25 \%$ respectively. The ages of the respondents can be reported as those who are less than 18 years were 15 $(6.25 \%)$, between 20 years and 25 years were $135(56.25 \%), 26$ years to 30 years were $20(8.33 \%), 31$ years to 35 years were $30(12.50 \%), 36$ years to 40 years were $32(13.33 \%), 41$ years to 45 years were $5(2.08 \%)$, and above 45 years were $3(1.25 \%)$. The respondents were asked of the number of years as customers of the telecommunication company chosen and their feedback was, respondents with 1 to 5 years as customers were $133(55.42 \%), 6$ to 10 years were $56(23.33 \%), 11$ to 15 years were $35(14.58 \%)$, and above16 years were 16 $(6.67 \%)$. Level of education statistics of the respondents are as follows; those with Junior High School education 
were 5 (2.08\%), Senior High School education was 23 (9.58\%), Bachelor was 120 (50.00\%), Masters were 56 $(23.33 \%)$ and Ph.D. were 36 (15.00\%).

Table 1 Descriptive statistics of Respondents

\begin{tabular}{|c|c|c|c|}
\hline Demographic constructs & & Size & Percentage \\
\hline \multicolumn{4}{|l|}{ Age } \\
\hline & less than 18 years & 15 & 6.25 \\
\hline & 20 years -25 years & 135 & 56.25 \\
\hline & 26 years - 30 years & 20 & 8.33 \\
\hline & 31 years - 35 years & 30 & 12.50 \\
\hline & 36 years - 40 years & 32 & 13.33 \\
\hline & 41 years - 45 years & 5 & 2.08 \\
\hline & above 45 years & 3 & 1.25 \\
\hline & & 240 & 100.00 \\
\hline \multirow[t]{3}{*}{ Gender } & male & 165 & 68.75 \\
\hline & female & 75 & 31.25 \\
\hline & & 240 & 100.00 \\
\hline \multirow[t]{5}{*}{ Years as customer } & $1-5$ years & 133 & 55.42 \\
\hline & 6 years -10 years & 56 & 23.33 \\
\hline & 11 years - 15 years & 35 & 14.58 \\
\hline & 16 years and above & 16 & 6.67 \\
\hline & & 240 & 100 \\
\hline \multirow[t]{6}{*}{ Level of education } & Junior High School & 5 & 2.08 \\
\hline & Senior High School & 23 & 9.58 \\
\hline & Bachelor & 120 & 50.00 \\
\hline & Masters & 56 & 23.33 \\
\hline & PHD & 36 & 15.00 \\
\hline & & 240 & 100 \\
\hline
\end{tabular}

\section{Results and discussion}

\subsection{Composite reliability and Cronbach Alpha}

The study performed a confirmatory factor analysis to ascertain the reliability of the constructs. Table 2 displays the results of the analysis and it can be confirmed that all the constructs were significantly reliable. The rule of thumb for Cronbach Alpha (CA) posits that the coefficient of the construct should exceed 0.7. However, where the composite reliability coefficient of a construct is within 0.7 and 0.9 , it is regarded as excellent, and where the coefficient is between 0.5 and 0.7 it is considered as moderate but when it is below 0.5 it is considered as low (Nunnally, 1978). It can be evidenced from table 2 that the composite reliability coefficient can report as 0.926 for value co-creation, 0.914 for customer perceived value 0.825 for innovation performance. All these values exceed the rule of thumb value hence the composite reliability coefficient of the constructs is excellent. Furthermore, the study with its confirmatory analysis of the constructs reports the Composite reliability coefficients in table, and it can be reported that all the coefficients of the constructs with regards to the composite reliability (CR) test are greater than 0.7 hence the rule of thumb that states that the coefficient should be greater than 0.70 is in measure (Gifen et al., 2000). Because, the CR coefficients of the constructs can be reported as $0.848,0.955$ and 0.832 for value co-creation, customer perceived value and innovation performance respectively which are all greater than 0.70 . The AVE can also be reported in table 2 and it can be ascertained that all the constructs are greater than 0.50 as the rule of thumb stipulates (Bagozzi \& Yi, 1988). Again, the loadings coefficients are greater than 0.50 confirming their reliability as the rule of thumb stipulates (Chin, 1998). 
Table 2 Constructs measurement Composite Reliability and Cronbach Alpha

\begin{tabular}{|c|c|c|c|c|c|}
\hline Constructs & Items & Loadings & $\mathrm{CR}$ & $\mathrm{CA}$ & AVE \\
\hline \multirow[t]{13}{*}{ Value co-creation (VC) } & VIU1 & 0.709 & 0.848 & 0.926 & 0.736 \\
\hline & VIU2 & 0.729 & & & \\
\hline & VIU3 & 0.880 & & & \\
\hline & VIU4 & 0.837 & & & \\
\hline & VIU5 & 0.574 & & & \\
\hline & COP1 & 0.704 & & & \\
\hline & COP2 & 0.764 & & & \\
\hline & COP3 & 0.835 & & & \\
\hline & $\mathrm{COP} 4$ & 0.777 & & & \\
\hline & COP5 & 0.722 & & & \\
\hline & COP6 & 0.715 & & & \\
\hline & COP7 & 0.734 & & & \\
\hline & COP8 & 0.698 & & & \\
\hline \multirow[t]{12}{*}{ Perceived value (PV) } & Q1 & 0.739 & 0.955 & 0.914 & 0.555 \\
\hline & Q2 & 0.799 & & & \\
\hline & Q3 & 0.806 & & & \\
\hline & E1 & 0.790 & & & \\
\hline & E2 & 0.758 & & & \\
\hline & E3 & 0.839 & & & \\
\hline & S1 & 0.838 & & & \\
\hline & S2 & 0.781 & & & \\
\hline & S3 & 0.820 & & & \\
\hline & $\mathrm{P} 1$ & 0.798 & & & \\
\hline & $\mathrm{P} 2$ & 0.900 & & & \\
\hline & P3 & 0.879 & & & \\
\hline \multirow[t]{2}{*}{ Innovation performance (PFR) } & PFR1 & 0.907 & 0.832 & 0.825 & 0.713 \\
\hline & PFR2 & 0.777 & & & \\
\hline
\end{tabular}

\subsection{Discriminant Validity of constructs}

The study found satisfactory evidence with regards to the discriminant validity coefficients of the constructs. The coefficients reported exceed the rule of thumb value of 0.70 . The study used two methods to evaluate the "discriminant validity" of the variables. The first method ensured that the cross-loadings of indicators should be greater than any other opposing constructs (Hair et al., 2012). The second method as established as Fornell and Larcker (1981) criterion, the square root of AVE for each construct should exceed the inter-correlations of the construct with other model construct (see Table 3). Hence, both approaches ensured the satisfaction of the results and validity.

Table 3 Discriminant Validity coefficients

\begin{tabular}{llllll}
\hline & PFR & VC & PV & COP & VIU \\
\hline PFR & $\mathbf{0 . 8 4 4 *}$ & & & & \\
VC & 0.607 & $\mathbf{0 . 8 5 8 *}$ & & & \\
PV & 0.568 & 0.710 & $\mathbf{0 . 8 8 3 *}$ & & \\
COP & 0.555 & 0.635 & 0.650 & $\mathbf{0 . 7 4 5 *}$ & \\
VIU & 0.610 & 0.520 & 0.687 & 0.725 & $\mathbf{0 . 7 5 4}^{*}$ \\
\hline
\end{tabular}

\subsection{Path Analysis}

With regards to the objectives of the study to examine the impact of value co-creation on innovation performance with the mediating effect of customer perceived value, table 4 represents the results of the path analysis conducted. From table 4, the results of the analysis accept H1 which reports a positive and significant coefficient of 0.666 at $1 \%$ significance level in support of (Heidenreich et al., 2015; Ranjan \& Read, 2016; Vega-Vazquez et al., 2013; Walsh et al., 2014). H2 is rejected due its insignificance but H4 is positive and significant with coefficient of 0.370 at $1 \%$ significance level. $\mathrm{H} 1, \mathrm{H} 2$, and $\mathrm{H} 4$ are direct effect relationships. Taking into consideration the indirect effects of the study, H3 is rejected due to its insignificance. However, H5 and $\mathrm{H} 6$ are all accepted at coefficients of 0.171 and 0.116 at $1 \%$ significance level respectively. H5 result is in support of studies from Ranjan and Read (2016), Yi and Gong (2013).

Table 5 displays the model fitness test for the study and it is evidenced the fitness of the models used for the study is moderate. The rule of thumb for model fitness postulates that when the coefficient value is 0.75 and 
above, it is considered as substantial, when it is within the range of 0.25 and 0.75 , it is considered as moderate and when it is below 0.25 , it is considered as weak (Hair et al., 2011). Hence the model fitness is considered as moderate as the coefficient of models 1,2 and 3 can be reported as $\mathrm{R}^{2}$ of $0.532,0.615$ and 0.575 whiles the adjusted $\mathrm{R}^{2}$ are $0.512,0.601$ and 0.569 respectively.

Table 4 Path Analysis and Hypotheses results

\begin{tabular}{llllllll}
\hline Effects & Hypothesis & Relationship & coefficient & S. E & T-stat. & P-value & Result \\
\hline Direct & & & & & & & \\
& $\mathrm{H} 1$ & $\mathrm{VC} \rightarrow \mathrm{PFR}$ & 0.666 & 0.086 & 7.744 & $0.000^{* * *}$ & $\begin{array}{l}\text { Accepted } \\
\text { Rejected }\end{array}$ \\
& $\mathrm{H} 2$ & $\mathrm{PV} \rightarrow \mathrm{PFR}$ & 0.242 & 0.173 & 1.399 & 0.163 & $\begin{array}{l}\text { Accepted } \\
\text { Indirect }\end{array}$ \\
& $\mathrm{H} 4$ & $\mathrm{VC} \rightarrow \mathrm{PV}$ & 0.370 & 0.149 & 2.483 & $0.000^{* * *}$ & \\
& $\mathrm{H} 3$ & $\mathrm{VC} \rightarrow \mathrm{PV} \rightarrow \mathrm{PFR}$ & 0.161 & 0.196 & 0.821 & 0.367 & Rejected \\
& $\mathrm{H} 5$ & $\mathrm{COP} \rightarrow \mathrm{VIU} \rightarrow \mathrm{PV}$ & 0.171 & 0.091 & 1.879 & $0.000^{* * *}$ & Accepted \\
& $\mathrm{H} 6$ & $\mathrm{PV} \rightarrow \mathrm{COP} \rightarrow \mathrm{VIU}$ & 0.116 & 0.097 & 1.196 & $0.000^{* * *}$ & Accepted \\
\hline
\end{tabular}

Table 5 Model fitness

\begin{tabular}{lllll}
\hline & Path & R square & Adjusted R square & Result \\
\hline Model 1 & PFR & 0.532 & 0.512 & Moderate \\
Model 2 & PV & 0.615 & 0.601 & Moderate \\
Model 3 & VC & 0.575 & 0.569 & Moderate \\
\hline
\end{tabular}

\section{Conclusion}

The study assessed the impact on value co-creation on innovation performance with a mediating effect of customer perceived value in the telecommunication industry in Ghana. The study used 240 respondents through an online survey which lasted for two months. The study concludes that value co-creation has positive and significant impact on innovation performance as displayed by the analysis performed. It is imperative for organization to ensure the participation of their customers and clients in value creation process. Customers involved and well regarded become customer for life and believe to be part of the organization. Value cocreation creates long term relationships between an organization and its customer which in the long run impacts the performance of the organization positively through relationship, experience, and continuous interaction.

\section{Limitation and future direction}

The study was conducted on the premise of Ghana which focused mainly on the telecommunication industry. However, one dimension was used for innovation performance which the study believes was not dynamic enough which is considered as the limitation to the study. The study could have extended its objective to assess the impact of value co-creation on specific innovation products and services of the telecommunication industry.

\section{References}

Bagozzi, R. P., \& Yi, Y. (1988). On the evaluation of structural equation models. Journal of the academy of marketing science, 16(1), 74-94.

Capegmini. (2007). Future consumer: How shopper needs and behaviour will impact tomorrow's value chain.

Carbonell, P., Rodriguez-Escudero, A. I., Pujari, D. (2009). Customer involvement in new service development: An examination of antecedents and outcomes. Jounal of Product Innovation Management 26, 536 -550.

Chesbrough, H. (2003). Open innovation. Cambridge: Harvard University Press.

Chesbrough, H., Vahenverbek, W., West, J. (2006). Open innovation: Researching a new paradigm. Oxford University Press.

Fellesson, M., Salomonson, N. (2016). The expected retail customer: Value co-creator, co-producer or disturbance? Journal of Retailing and Consumer Services, 30, $204-211$.

Fornell, C., \& Larcker, D. F. (1981). Structural equation models with unobservable variables and measurement error: Algebra and statistics: SAGE Publications Sage CA: Los Angeles, CA.

Galvangno, M., Dali, D. (2014). Theory of value co-creation: a systematic literature review. Managing Service Quality, 24(6), $643-683$.

Internet World Statistics (2013). Ghana Internet usage and telecommunications. Retrieved 6 June, 2013.

Global Commerce Initiative. (2008). Succeding in a volatile market.

Gronroos, C., Vioma, P. (2013). Critical service logic: making sense of value creation and co-creation. Journal of the Academy of Marketing Science, 41(2), 133 - 150.

Hair, J. F., Ringle, C. M., \& Sarstedt, M. (2011). PLS-SEM: Indeed a silver bullet. Journal of Marketing theory and Practice, 19(2), 139-152.

Hair, J. F., Sarstedt, M., Ringle, C. M., \& Mena, J. A. (2012). An assessment of the use of partial least squares 
structural equation modeling in marketing research. Journal of the academy of marketing science, 40(3), 414-433.

Hoyer, W. D., Chandy, R., Dorotic, M., Krafft, M., Singh, S. S. (2010). Consumer coccreation in new product development. Journal of Service Research, 13 (3), 283.

Ind, N., Coates, N. (2013). The meanings of co-creation. European Business Review, 25(1), 86-95.

Kotler, P., Keller, K. L. (2012). The meanings of co-creation. European Business Review, 25(1), 86- 95.

Kristensson, P., Matthing, J., Johnasson, N. (2008). Key strategies for the successful involvement of customers in the co-creation of new technology-based services. International Journal of Service Industry Management, 19(4), $474-491$.

Lawer, C. (2006). Eigth styles of firm-customer knowledge co-creation. OMC Group.

Leroi-Werelds, S., Streukens, S., Brady, M. K., Swinnen, G. (2014). Assessing the value of commonly used methods for measuring customer value: a multi-setting empirical study. Journal of the Academy of Marketing Science, 42(4), $430-451$.

Lusch, R. F., Vargo, S. L. (2006). Service-dominant logic: reactions, reflections and refinements. Marketing Theory, 6 (3), $281-288$.

Lusch, R. F., Vargo, S. L. (2009). Exploring the contributions of involving ordinary users in ideation of technology-based services. Journal of Product Innovation Management, 26, 578 - 593.

Martelo Landroguez, S., Barroso Castro, C., Cepeda-Carrion, G. (2013). Developing an integrated vision of customer value. Journal of Services Marketing, 27(3), $234-244$.

Nambisan, S., Baron, R. A. (2009). Virtual customer environments: Testing a model of voluntary participation in value co-creation activities. Journal of Product Innovation Management, 26(4), 388 - 406.

Pater, M. (2009). Co-creation's 5 guiding principles. Amsterdam: Fronteer Strategy.

Pierre, C. (2016). The relationship between value Co-creation and customer perceived value (published Master dissertation). University of Pretoria, South Africa.

Pine, B. J., Gilmore, J. H. (1999). The experience economy: Work is theatre and every business a stage. Boston: Harvard Business School Press.

Prahalad, C. K., Krishan, M. S. (2008). The new age of innovation: Driving co-created value through global networks. Columbus, OH: McGraw-Hill.

Prahalad, C. K., Ramaswamy, V. (2004). Co-creation experiences: The next practice in value creation. Journal of Interactive Marketing, 18, 5 - 14 .

Prahalad, C. K., Ramaswamy, V. (2000). Co-opting customer competence. Harvard Business Review, 78 (1), 79 -88 .

Prahalad, C. K. Ramaswamy, V. (2004). The future of competition: Co-creating unique value with customers. Boston, MA: Harvard Business School Press.

Ranjan, K. R., Read, S. (2016). Value co-creation: concept and measurement. Journal of the Academy of Marketing Science, 44(3), $290-315$.

Salomo, S., Steinhoff, F., Trommsdorff, V. (2003). Customer orientation in innovation projects and new product development success and the moderating effect of product innovativeness. International Journal of Technology Management, 26, $442-463$.

Sanchez-Fernandez, R., Iniesta,-Bonillo, M. A. (2007). The concept of perceived value: a systematic review of the research. Marketing Theory, 7(4), 427-451.

Statistics of Ghana "World Bank". Retrieved on June, 2013

Sweeny, J. C., Soutar, G. N. (2001). Consumer perceived value: The development of a multiple item scale. Journal of Retailing, 77(2), $203-220$.

Tatikonda, M. V., Montoya-Weiss, M. M. (2001). Integrating operations and marketing perspectives of product innovation: The influence of organizational process factors and capabilities on development performance. Management Science, 47 (1), $151-172$.

Tijmes, A. H. (2010). Co-creation and firm performance: innovation success enhancing effects of and motives for customer involvement.

Vargo, S. L., Lusch, R. F. (2004). Evolving to a new dominant logic for marketing. Journal of Marketing, 68, 1 17.

Vargo, S. L., Lusch, R. F. (2008). Service-dominant logic: continuing the evolution. Journal of the Academy of Marketing Science, 36, $1-10$.

Vega-Vazquez, M., Angeles Revilla-Camacho, M., Cossio-Silva, J. F. (2013). The value co-creation process as a determinant of customer satisfaction. Management Decision, 51(10), $1945-1953$.

Von Hippel, E. (2005). Democratizing innovations. Boston, MA: MIT Press.

Walsh, G., Shiu, E., Hassan, L. M. (2014). Replicating, validating and reducing the length of the consumer perceived value scale. Journal of Business Research, 67 (3), 260 - 267. 